\section{The concerns associated with future prospects of the food cart business in Chittagong, Bangladesh: is the concept of halalan tayyiba missing link?}

\author{
Ariful Islam and Sazali Abd Wahab
}

Putra Business School (AACSB-Accredited), University of Putra Malaysia (UPM), Serdang, Malaysia

\begin{abstract}
Purpose - The informal segment compared to the formal segment is developing rapidly in urban areas of many developing Muslim countries. However, matter of fact, the contribution factor of the food cart business to the economic outline of the country has been vastly overlooked or neglected. The authority, policymakers, social organisations, vendors and the customers together need to play a contributing role based on intervention tactics regarding the major focus areas related to the development of this business segment. As a result, this study aims to explore concerns or issues that are hampering future business prospects considering the philosophy of halalan tayyiba.

Design/methodology/approach - The study has organised 16 semi-structured interview procedures with relevant food cart vendors of Chittagong, Bangladesh. The study selected participants (food cart vendors) from lower- to medium-income areas occupying at least one high school, one college in relation to several commercial premises (ex-mini shopping malls, offices and small factories) considering 6 out of 41 wards of Chittagong city corporation. All meetings with reflected participants were audiotaped and transcribed verbatim and transcripts were loaded into NVivo for coding and analysis procedure.

Findings - This investigation revealed that issues with food security, weather, lack of proper legislation, lack of awareness related with halalan tayyiba and erratic policies are the major challenges for the development of the food cart business in Chittagong. This study also advances how street food security wellbeing and hygiene practices are a piece of the halal idea and should in this way be adjusted by the halal food segment to accomplish halalan tayyiba affirmation. The outcomes also indicate an agenda for future research in this area.
\end{abstract}

Research limitations/implications - More reflections from the different stakeholders do have both pertinence and potential for incorporation in suggestions.

Practical implications - The detected findings may help both authority and other concerned entities to identify the critical dynamics to initiate appropriate strategic activities towards local economic growth considering halalan tayyiba outlines.

(C) Ariful Islam and Sazali Abd Wahab. Published in Rajagiri Management Journal. Published by Emerald Publishing Limited. This article is published under the Creative Commons Attribution (CC BY 4.0) licence. Anyone may reproduce, distribute, translate and create derivative works of this article (for both commercial and non-commercial purposes), subject to full attribution to the original publication and authors. The full terms of this licence may be seen at http://creativecommons.org/licences/by/4.0/legalcode

This paper and the research behind it would not have been possible without the exceptional influence of Ariful Islam's late father, B.A.M. Serajul Islam. His enthusiasm, knowledge and wisdom have always been an inspiration for the author and kept his work on track. He is grateful for all the sacrifices his father made for him and his family.
Food cart 
$\begin{array}{ll}\text { RAMJ } & \text { Social implications - It will ensure social well-being and food security. } \\ \text { 16,1 } & \text { Originality/value - This explorative research is one of few studies in the Bangladesh context, which is } \\ \text { investigating halalan tayyiba-oriented business development outline for micro entrepreneurs. }\end{array}$

Keywords Legislation, Street food, Tasawur, Sharī'ah

Paper type Research paper

\section{Introduction}

The business idea associated with the modern food cart goes back to as right on time as 1866 with the emergence of the "chuckwagon" concept to assist meandering cattlemen regarding their daily nutrition requirements in Texas, USA (Sen et al., 2018). Since the late 2000 s, be that as it may, food cart ubiquity has detonated catching the consideration of regular consumers and business entrepreneurs, as well as policymakers and authorities. Various speculations exist for the dramatic increase in the numbers of food cart vendors or sellers throughout the global premises. In numerous parts of the world, especially in the developing regions, ranges of street food distributing by food carts additionally make a critical commitment to business or employment prospects, revenue source and nutrition security (Alimi, 2016). Actually, food cart speaks to a prospect, yet very scattered or unstructured business segment in Bangladesh. However, these food carts are also a basic source of sustenances for individuals with low pay, workers, students and an option of occupation for some in the country (Redzwan Habib, 2016). While food carts are a critical source of ready-to-eat meal or snacks for the general population of the country, the health and hygiene or other threats controlled by such street foods may possibly exceed their advantages. As a densely populated, low income Muslim country the popularity of street foods delivered from food carts is increasing day by day in Bangladesh and holds a bright business prospect for future days to come considering Islamic outlines. In fact, the halalan tayyiba principle is one of the Sharīah rules intended to safeguard the decency of human life as to promote the best dietary habit grant by Allah SWT.

In many emerging regions, informal segment (ex-street food vending through food cart) referring to underground economy accounts for a third to half of the total economy. Bangladesh has no exception. Large portion of this informal sector is actually legal but remains informal. Bangladesh's informal economy constitutes $35 \%-78 \%$ of the total economy (Hassan, 2018). Although this sector might help the economic growth in the short run, but in the end, it obstructs the trajectory of development due to less productivity. Moreover, a large informal economy is actually exhibiting policy failures and significant discrimination (Truong, 2018). The matter of street food vending from food carts is an influential factor within the mechanism of urban informal economy (Bhowmik, 2012; Bromley, 2000). Street foods selling from food carts selling are commonly seen as informal activities in sub-continent areas, and mostly uncontrolled trading occurs in public spaces such as streets, sidewalks, bridges and pavements (Ghatak and Chatterjee, 2018; Sigwele et al., 2017). Following many attempts by authority to eliminate food carts, it remains a thriving trend in many cities as there is demand from a huge low or medium income population that gains from buying cheap food products (Martínez et al., 2017). Food cart business provides jobs and income serves as a livelihood strategy for the urban poor; thus, it is a complex mechanism in which people participate in building their livelihoods. Although greater attention is given to the correlations of micro entrepreneurship-poverty alleviationeconomic development in different regions (Adhikari, 2017; Hassan, 2018), minimal research work takes into account the concerns of street food vending in Bangladesh, considering food carts, who constitute the informal economic outline. 
From another angle, vendors selling food from food carts could not have access to pure water, water disinfection process, suitable toilet facilities, refrigeration or the means in their business setting for appropriate sanitary practices (Ghatak and Chatterjee, 2018). They may lack the awareness or motivation to use them to produce and sell healthy food even if they do have these resources (Rahman et al., 2016). Based on the 2015 Ministry of Health statistical survey, the number of food-borne illnesses is usually from the street foods selling from food carts or stalls (Shafiee et al., 2017). At this point, the study assumes that the adoption of halalan tayyiba can possibly serve as a suitable standard or guideline within the interplay between the informal and formal economic outline of Bangladesh to safeguard future business prospects of the food cart business segment. According to MIFC (2015) report, the estimated global expenditure of Muslim consumers in the food and lifestyle sectors reported in 2013 is US\$2tn and is projected to rise to US $\$ 3.7 \mathrm{tn}$ by 2019 at a compound annual growth rate of $10.8 \%$. The latest trends are precisely evident of huge market aspects and a rapid enhancement of the global halal food industry (Bohari et al., 2017). Halal food is necessary if the Islamic principles of safety, hygiene and quality are to be fulfilled. Though global Muslims support halal food because of their religious responsibilities, non-Muslims often turn to Halal food because of the concerns about unhygienic and unsafe foods (Zailani et al., 2019). Here the idea of halalan tayyiba considers to humanity all of the physical and spiritual benefits of the food items. In this respect, halalan tayyiba can be a realistic protocol to street foods (halal) selling from food carts, which can benefit human wellness (Alzeer et al., 2018). However, it is a matter of regret that the reciprocity between halalan tayyiba and the future prospect of the food cart business segment has been very constrained or somehow ignored by researchers on the context of Bangladesh. In fact, there have been many extremist incidents, which may possibly create an environment of discouragement and cynicism in Bangladesh about halal belief on basis of contradictory perspectives and views (Nisha and Iqbal, 2017). As per discussed contexts, the study targets a twofold objective to explore some of the key concerns related with suitable development strategy of food cart-related business to guide the policymakers towards necessary intervention tactics considering the principals of halalan tayyiba.

\section{Literature review}

In reality, Allah SWT has made it necessary for each Muslim to devour sustenance or food that is halal (legal) and of good quality with adequate minerals and nutrients as required. These two perspectives that are halal and of best quality would not just guarantee physical well-being and readiness, however, will likewise be a push factor that will expand the nature of one's taqwa (good deeds) and syukur (gratefulness) towards Allah SWT. The Arabic word halal means something that is permitted through Allah SWT (Rezai et al., 2015). The inverse is haram, which implies absolutely not permitted or illegal. As per the principal of Islamic jurisprudence (Usul Fiqh) it is characterised as something that must be abstained from as indicated by the Islamic law (U1 Ain, 2017). Another major aspect needs to be given attention is the word tayyib, which generally reflects the relation towards food in general, but it also covers different conditions, for example, one's expectations, words, acts and convictions (Arif and Sidek, 2015). At this point, the use of the term tayyib in the holy Qur'an is always related with the acceptance of a particular conduct whereas tayyib as a quality of standard for food items (Zainuddin and Shariff, 2016). The halalan tayyiba idea must be seen as integrated form by tactical method for its inside and outer angles. The study of Muhamad et al. (2016) also describes that the present trend of Muslim consumers holds motivation towards Islamic rules and teachings in their lifestyle and business activities. As such, the integration of halal tayyiba concept with the food service industry can possibly 
RAMJ

16,1

increase huge development potential for growth of focussed industry. It is imperative that this idea be totally comprehended as it is a standard to measure business potential, nature of food security and consumerism related to the food cart business segment.

However, a food cart is generally a portable lightweight kitchen option that is set up in different places of the city or roadside to encourage the selling of street foods to individuals from the nearby pedestrian activity (IAFP, 2015). These carts are frequently found in extensive urban areas all through the world and can be discovered offering street foods of pretty much any variety. They are normally located outdoors or under shades/roofs, which is easily reachable from the main street (Ghatak and Chatterjee, 2018). In light of low capitalisation and solid gaining potential, food carts have turned out to be a standout amongst the most favoured kinds of new entrepreneurship for some individuals. Not at all like formal occupation segments, the food cart business requires no earlier abilities or enactment and includes low speculation for a startup of the business (Al Mamun et al., 2013). In fact, the food cart vendors are a self-employed dimension of small or micro entrepreneurship setup who are not generally dependent on any institutional outline to find their earnings. On the other hand, street foods can be explained from the formal food sector by its definition. The Equity Policy Sector denotes the road street foods that is sold from carts or bushels or balance shafts or from mini shops having less than four perpetual dividers (Sen et al., 2018). Generally, street foods often indicate traditional domestic cultures and exist in an endless range. There is a different situation in the utilisation of street food options around the globe, for instance, in Mali a poor family spends through $20 \%-27 \%$ of the normal family expenses on street foods (Bendech et al., 1997). However, one can envision the significance of street foods not just for the sustenance or food security of the urban poor of the country, yet in addition for the functionality of the urban economic outline as such. At this point, diversification is generally seen as the most effective strategy for reducing the risk to livelihoods (Nani, 2016). Evidence suggests that economic shocks or crises more than the average affect disadvantaged groups, and that leaders of the economy's informal sector belong to that category (Bhuvaneshwari and Venkatachalam, 2018). Street food selling through food cart providing jobs and income acts as a livelihood strategy for the urban poor.

A few people argue that food carts are just a craze, a perusing of Jane Jacob's "The Economy of Cities" proposes that new wave food carts or food trucks may really speak to the introduction of another prospective business industry (Jacobs, 1969). In such a manner, the rise of the food cart business is illustrative of an outstanding pattern in monetary improvement wherein established business sectors deliver emerging trends in response to shifting core market dynamics. Thusly, the food cart industry displays a chance to additionally investigate how, and under what conditions new entrepreneurship ventures advance from existing ones, and what the effects of these businesses are on local economic outlines (Batréau and Bonnet, 2016). In adjusting this concept to the effects of this industry, food carts selling street foods turn out to be progressively more applicable to the field of monetary improvement, particularly as they identify with urban renewal, business entrepreneurship options and issues relating to market guidelines or policies. As the food cart business sector keeps on picking up energy in of all shapes and sizes urban communities alike, the local authority are being compelled to intervene conflicts between sellers, city policies and opposition segments (Sharma, 2017).

The urban populace in Bangladesh is expanding very quickly. In the most recent decade, the number of individuals living in the nation's second-largest city Chittagong relatively multiplied up to 3.5 million at metro area (Rahim and Choudhury, 2015). This city is also a very famous tourist destination of the country amongst locals and internationals. However, fast urbanisation likewise moved street foods selling through food carts towards a vital 
business; in Chittagong alone, around $\pm 30,000$ individual food cart vendors manage their living by offering various street food items (Khairuzzaman et al., 2014). In point of fact, a vast scale relocation of rural individuals to urban regions street foods selling through food carts has turned into a developing casual part in the urban zones in numerous nations in Asia, including the city of Chittagong, Bangladesh. The minimal effort, availability and comfort are the key elements for the developing prominence of this business opportunity. The female populace assumes an exceptionally crucial role in the focus area through their direct or potentially backhanded inclusion in the business (Islam, 2016). In reality, the utilisation examples of food cart vendors and their commitment to dietary admission are scanty. The researchers also uncovered that the fundamental consumers of street foods in many the country are different individuals from the informal area, for example, fellow vendors and hawkers and daily paid workers. The imperative classes of customers also include students, service holders and housewives (Warr, 2014).

In reality, lack of awareness, expertise about safe food management tactics in relation with absence of essential regulatory frameworks or guidelines to guarantee proper food hygiene and positive social impact are considered as a concern for this business segment around Asian regions including Bangladesh (Frank, 2015). The study of Proietti et al. (2014) also indicate that limited understanding about consumer right acts from both ends, insufficient regulatory standards about food cart business, no requirement of identity (ID) card, no dress code, absence of training programmes and limited number of sanitary inspections may possibly other barriers for the development of this segment aligned with national or local economic objectives. By taking the benefit of poor monitoring and control tactics, food cart businesses especially in Bangladesh regularly are arranged and sold in an unhygienic way that is accepted to be a key reason of waterborne diseases. Poor learning about safe street food management practices alongside the absence of an essential framework to guarantee cleanliness is considered as a noteworthy general well-being hazard (Muzaffar et al., 2009). Alongside defencelessness of business and income, the street food sellers through food carts regularly are subject to expulsions and provocation. The little food carts used for distributing or selling are for the most part set up illegally without any kind of permit from the concern authority. They regularly confront removals from police or legal organisations or by neighbourhood powerful individuals (Ali et al., 2012). They frequently need to adapt to the appropriation of their gear or aggregate uprooting from vending locations. On the other part, because of the conditions under which street foods are sold, there is worry that food items might be defiled with overwhelming metals and pesticide buildups. These contaminants may originate from the utensils, crude materials or transport techniques used and may likewise happen because of the absence of proper storage tactics (Proietti et al., 2014). In addition, the sellers or vendors do not have sufficient washing options, and a few vendors began their obligations without a proper bath. In fact, a number of the vendors rest at the selling destination to ensure the security of their food carts and items. The street foods are likewise subjected to rehashed tainting from unwashed hands and the materials used for wrapping, for example, leaves, old daily papers and reusable polyethylene packs (Webb and Morancie, 2015).

The food security legislation and regulatory adjustment of street foods distributed through food carts varies from region to region. An ongoing audit of the circumstance in Asia discovered incredible assorted variety amongst the lawful instruments created to control this business. Some countries do not practice specific legislation or regulatory systems at all (Pritchard and Chan, 2016). In those Asian countries where food cart business activities were managed by law, the controls or by laws influencing the street food selling were a piece of a bigger group of enactment managing sustenance, well-being or ecological 
RAMJ

16,1

sanitation. The licensing or registration process, inspection outline and guidelines of sustainable practices are other forms of regulation that are in effect in some countries (Di Matteo and Cavuta, 2016). However, various legislations identified with preparation process, sales guideline, location regulations that are linked to safe and hygienic street foods business outlined by the Bangladeshi Government. The Bangladesh pure food ordinance 1959 revised at 2005 holds several clauses related with food security part of this business, such as: precaution about contamination, restriction of calcium carbide, formalin, etc. restriction regarding unhygienic premises, selling uncovered foods and violation of health codes (Rahman, 2016). The other legislations or measures to ensure food safety are Bangladesh Standards and Testing Institute ordinance 37 of 1985, the consumer's rights preservation act 2009 and the penal code of 1869 (section 272-276). On the other part, Bangladesh Islamic Foundation is the only authorised organisation to provide halal certification. Again, a range of civil community organisations have emerged in recent timespans to promote food safety of street foods distributed through food carts. The organisations such as the consumer association of Bangladesh, Bangladeshi Consumer's Association (VOCTA) (consumer) directed surveys, awareness programme through seminars, workshops to ensure overall food safety for the consumers. In addition, the role of electronic and print media is also notable considering the concern related with awareness of safe street foods in Bangladesh (Islam, 2015). However, there are still options for policymakers to obtain more insights and formulate an intervention strategy considering food safety with other related issues for the development of this business segment leading to the economic growth of the local government.

\section{Theoretical perspective of the study}

The institutional theory is an increasingly adopted theoretical lens for micro entrepreneurship investigations. Starting with Shane and Foo's (1999) investigation of diversifying achievement, institutional theory is assuming a noteworthy role in clarifying the powers that shape entrepreneurial success, aside from authoritative (or innovative) assets (Peng, 2001). This theory is thus, concerned with regulatory, social and cultural influences that promote survival and legitimacy of an organisation rather than focussing solely on efficiency seeking behavioural pattern (Bruton et al., 2010). At this point, regulative components stem essentially from authoritative compliances and industrial agreements or standards. These regulations give guidelines to new entrepreneurship ventures and can lead to organisations consenting to laws and furthermore singular consistence with laws or may require a response if there is an absence of law or control in the enterprising firm's premises. The another institutional column is the normative one, which speaks to models of organisational and singular conduct dependent on compulsory components of social, professional and hierarchical connection. At last, the cognitive column abridged by Sizonenko (2013) and got vigorously from the recent intellectual turn in sociology (Weik, 2011) speaks to models of individual conduct dependent on abstractly and (regularly continuously) developed standards and meanings that limit fitting convictions and activities. Matter of fact, the institutional elements affecting innovative endeavours incorporate the immediate activity of governments in building and keeping up a domain steady of business entrepreneurship in micro level and societal standards towards enterprise.

\section{Methodology}

The basis for explorative study outline is the acknowledgment that the information assembled would be from individual sources, and along these lines conceivably abstract 
conclusions. Here, the study is exploratory and no cause and end effect relationship was being tested, nor was a clarification of associations being looked for. The research initiative has consumed a qualitative investigation design in association with the purposive judgemental sampling method. The study selected participants (food cart vendors) from lower to medium income areas occupying at least one high school, one college in relation with several commercial premises (ex-mini shopping malls, offices and small factories) considering 6 out of 41 wards of Chittagong city corporation such as South Pahartali (Ward 1), West Solasahar (Ward 7), Sulakbahar (Ward 8), West Bakalia (Ward 17), Chandgaon (Ward 4), Chawkbazar (Ward 16) and Jamal Khan (Ward 21), which is basically founded on the criteria set for the research. This sampling method indicates a deliberate selection of interviewees. In fact, the process of personal follow-up visits occurred to each food card for generally two to three visits per cart. Some food orders were required to be executed to obtain interviews in some of the cases. The most common cause explained by food cart vendors for avoiding interview participation was their shortage of time. However, the study initially aimed for 20-25 interview sessions but data saturation level was obtained hastily, such that no fresh codes were produced from the last several interviews.

Here semi-structured interview procedure was used for its suitability for exploring insights about various topics of concern. The interviewees were investigated and sorted out into substantial concern-related groupings from which the centre topic had inferred. Before executing an interview procedure, selected respondents were served basic information about research details and given a declaration about their identity security. All interview sessions took place on the premises of respective food carts and lasted approximately 10-20 min on basis of fixed appointments. The participants who helped to execute the interview sessions received small gift hampers as a token of appreciation in recognition of their valuable time. The whole procedure was completed within 6 to 8 weeks timeline.

All meetings with reflected participants were audiotaped and transcribed verbatim, and transcripts were loaded into concern software for coding and analysis procedures. The procedures related with interviews, audio recording and coding activities were all performed by a single researcher, safeguarding the optimum degree of acquaintance with the collected data. Here some primary information also collected from field observations by the researcher. In addition, non-government organization reports, thesis, project papers and documentary videos have also been used for the study as sources of supportive information regarding the identified concerns. At this point, the triangulation process of the analysed information has been established to enhance the validity and reliability of the research process.

\section{Results and analysis}

A total number of 16 semi-structured interviews are conducted amongst food cart vendors inside Chittagong metropolitan city. Out of 16 food carts vendors, 2 are female vendors. The maximum numbers of participants are between the age group of 20-30 years. Here in Chittagong city the food cart vendors selling various ranges of delicious street foods from Western or Indian to pure local such as fuchka/chatpati/chola or biriyani. With appropriate promotional tactics, this vibrant menu holds the prospect to attract local and international food visitors in near future considering the city's famous tourist attractions (Table 1).

Another obtained insight is that maximum of the food vendors hold at least primary level of education (50\% of the food-cart vendors). There are also presences of degree level students who are contributing to this business segment as their part time income option (three participants). The students who are doing business activities along with their studies can possibly indicate an affirmative contribution towards the local economy. On the other 


\begin{tabular}{|c|c|c|c|c|c|}
\hline $\begin{array}{l}\text { RAMJ } \\
16,1\end{array}$ & $\begin{array}{l}\text { Participant } \\
\text { code }\end{array}$ & Type of street food & Location of food cart & Years in business & Education \\
\hline \multirow{4}{*}{28} & SH1 & $\begin{array}{l}\text { Singara/samusa/ } \\
\text { potato chop }\end{array}$ & Nearby street of a collage & 1.5 years & Primary \\
\hline & $\mathrm{SH} 2$ & Fuchka/chatpati & Nearby street of a school & 3.5 years & Primary \\
\hline & SH3 & Fuchka/chatpati & Just outside of wet market & 2 years & Primary \\
\hline & SH4 & Juice/fruits & Nearby street of a school & 1 year & $\mathrm{SSC}$ \\
\hline & SH5 & Biriyani/tehari & Nearby street of a collage & 1 year & No education \\
\hline \multirow{12}{*}{$\begin{array}{l}\text { Table } 1 \text {. } \\
\text { The demographic } \\
\text { data of food cart } \\
\text { vendors }\end{array}$} & SH6 & $\begin{array}{l}\text { Curry/paratha/ } \\
\text { kebab }\end{array}$ & Nearby street of a collage & 6 months & $\begin{array}{l}\text { Degree } \\
\text { (ongoing) }\end{array}$ \\
\hline & SH7 & Boiled egg & Just outside of wet market & 1 year & Primary \\
\hline & SH8 & $\begin{array}{l}\text { Chola/beguni/ } \\
\text { pakoda }\end{array}$ & Just outside of wet market & 4 months & Primary \\
\hline & SH9 & $\begin{array}{l}\text { Burger/ } \\
\text { subsandwich }\end{array}$ & Just outside of shopping mall & 6 months & $\begin{array}{l}\text { Degree } \\
\text { (ongoing) }\end{array}$ \\
\hline & SH10 & Fried chicken & $\begin{array}{l}\text { Nearby street of a private } \\
\text { university }\end{array}$ & 6 months & HSC \\
\hline & SH11 & Tea/coffee/snacks & $\begin{array}{l}\text { Nearby street of a private } \\
\text { university }\end{array}$ & 1 year & $\mathrm{SSC}$ \\
\hline & SH12 & Biriyani/tehari & Just outside of shopping mall & 8 months & $\mathrm{SSC}$ \\
\hline & SH13 & Fuchka/chatpati & Nearby street of a school & 2 years & Primary \\
\hline & SH14 & Momo/noodles & $\begin{array}{l}\text { Just beside the entrance of a } \\
\text { shopping mall }\end{array}$ & 6 months & $\begin{array}{l}\text { Degree } \\
\text { (ongoing) }\end{array}$ \\
\hline & SH15 & Chola/beguni/ & Nearby playing field & 2 years & Primary \\
\hline & SH16 & $\begin{array}{l}\text { pakoda } \\
\text { Fuchka/chatpati }\end{array}$ & $\begin{array}{l}\text { Just beside the entrance of } \\
\text { city corporation office }\end{array}$ & 1.5 years & Primary \\
\hline & \multicolumn{5}{|c|}{ Source: Compiled from interview procedures } \\
\hline
\end{tabular}

part, the duration of the business detects that majority of the vendors are new in this business with limited expertise (one year or less than one year). A large amount of food cart vendors are acquainted with this business through their relatives or companions or through past associations. Most of the vendors met were occupied with some different occupations previously beginning this business, e.g. retail shop employee, readymade garments worker, waiter, daily labour and so forth. However, the trend points uprising prospect curve for this business option whereas it also points the common barriers or vulnerability issue associated with this business throughout Chittagong premises. Again the location preference in the present study indicates the unregulated tendency to place their food-carts beside busy streets or footpaths or public gatherings (Table 2).

Street foods distributed from food carts in the city require a far reaching suitable policy or outline to guarantee that served food is protected and healthy. Food borne or waterborne illnesses of microbial nature are a major health issue related to this business (Khairuzzaman et al., 2014). Approximately, more than 30 million populace of the country are suffering from food borne sufferings each year (Rahman, 2016). Here the findings show that keeping the street foods covered is rarely practiced amongst almost $50 \%$ of the reflected vendors that reveals the great threat of contamination. However, the participant SH13 explains the reason behind this scenario as:

[...] customers want to see the food before making any purchase decision. They always looking for delicious looking foods from food-carts. 


\begin{tabular}{|c|c|c|}
\hline The major concerns related with food cart business & $\begin{array}{l}\text { The no. of } \\
\text { participants } \\
\text { identified } \\
\text { with that concern }\end{array}$ & $\begin{array}{l}\text { Food cart } \\
\text { business }\end{array}$ \\
\hline $\begin{array}{l}\text { Food security } \\
\text { [a] Not covering the street foods } \\
\text { [b] Use of water from unreliable sources (not filtered)/use of supply water } \\
\text { [c]Personal hygiene }\end{array}$ & $\begin{array}{l}{[\mathrm{a}] 7} \\
{[\mathrm{~b}] 3} \\
{[\mathrm{c}] 4}\end{array}$ & \\
\hline $\begin{array}{l}\text { Weather (flood water due to heavy rainfall) } \\
\text { No trade license/registration }\end{array}$ & $\begin{array}{l}12 \\
5\end{array}$ & \\
\hline Lack of knowledge about the concept of halalan tayyiba & 10 & Table \\
\hline $\begin{array}{l}\text { Location of foodcart is the cause of moderate to heavy traffic/obstacle to pedestrian } \\
\text { activities }\end{array}$ & 5 & The major concern \\
\hline Unlawful bribery from patrol police/local political gang members & 12 & $\begin{array}{r}\text { related with food-cart } \\
\text { business in }\end{array}$ \\
\hline Source: Compiled from interview procedures & & Chittagor \\
\hline
\end{tabular}

In spite of the fact that few of them appear to realise that revealed street food harbour flies or different creepy crawlies and this can cause illness amongst the buyer, however, they either appear not to think much about it. In addition, some vendors alarmingly use deep tube-well water or water from unreliable sources for their daily operational activities. The use of common supply water is very common amongst street food vendors. The interviews explore that number of vendors live in messy places where there exists a lack of option to filter or purify water properly, as a result, it is beyond their capacity to ensure guaranteed safe food, water or even hygiene factor. Again, a comparative situation was discovered in regard to handwashing practice with soap after using toilet facilities. Despite the fact that a decent number of vendors have handwashing practice with cleanser after using the toilet, in case of the others this is not being practiced in the family either. An exceptionally regular practice is using a same unclean towel to clean the shop, plates, cups or even to dirty hands. Additionally, a maximum of the vendors were found to store daily garbage either on the truck or in poly bags or in a revealed close by bin. However, the implementation of suitable safety outlines through tactics to proper hygiene exercises by vendors and also customers may possibly reduce the risk factor of street food consumptions (Alimi, 2016). Most importantly, the dynamic coordinated effort of all partners towards the reinforcing and appropriate implementation of general health and safety arrangements to guarantee safe practices and cause a more secure and more beneficial society is prescribed.

The city of Chittagong is attached with coastal areas and off shore islands. The average height from the level of the sea is less than $3 \mathrm{~m}$. Heavy rainfalls during rainy season and cyclones are very common throughout the region. There is also the existence of flooding problem especially in time of heavy rainfalls due to improper drainage system in the city. Sometimes food cart vendors cannot operate their business for days due to above mention weather-related issues. One of the participants describes the misery as:

$[\ldots][\ldots]$ in this month my income from business is very poor. Don't know how pay fees for my 3 school going children! The flooding caused by rainfall is the biggest barrier for daily business. I have never noticed city corporation people cleaning those drains or something.

Weather is always a challenge for food cart business around coastal regions as the vendors only expect $50 \%$ of the average revenue during the rainy days (Bujisic et al., 2016). By introducing delivery services, the vendors may reduce the impact of the revenue scenario. In 
RAMJ

16,1

fact, the vendors need to monitor the weather forecast regularly whereas the authority needs to outline policy and strategy regarding the specific secured location with shades and other needed facilities for these food-carts.

The obtained insights from interviews shows that nearly one-third of the reflected vendors do not contain or hold any kind of registration or trade license from concern authority. When discussed about taking a license or permit from the local authority if arranged, more than four vendors were not willing to take one as they think for such a little business setup a permit is not necessary or they have to pay a regular high amount or tax if they take a license. Indeed, even the vendors who were eager to take a permit said it will be a long procedure and communicated their worry that they may even need to pay off extra money to get one. In addition, there is also no provision of a dress code or ID card or any kind of sustainable guideline from the authority. The most squeezing and progressing threat for some vendors is the likelihood that local authority or city corporation officials will coercively expel them from their locations or confiscate their stocks. This threat of relocation frequently uprises with regard to elections, mega events or endeavours to beautify memorable downtown areas. Much the same as formal business administrators, food cart vendors are less beneficial in unsteady institutional situations where rules are paradoxical or irregular (Pinstrup-Andersen, 2000). The legal status of food cart vendors can possibly contribute as a connection between their employment conditions and the range of employment threats they face daily. Again, a vendor with semi fixed structure in association with a fixed location approved by the authority, as instance, may possibly more likely to embrace a license or permission, and, in turn, would be less exposed to certain kinds of business threats (Shamtsyan, 2013). On the other part, the issues of harassment and demand for daily bribes by local authority (mainly patrol police) and local political leaders are very much common in this business scenario. In a matter of fact, the issues and concerns the food cart vendor encounter need the special attention of the authorities concerned.

Another important concern that needs further focus here is the politics or informal security cash issue inherent in the domination of urban public locations for food cart business. As mentioned, the business potential hugely depends on their integration in informal networks of the area. The social connection with powerful figures in the arena gives them access to prospective locations on the street, pavement or other prospective open spaces (Hackenbroch, 2013). The study reveals that informally, most of the vending spaces or spots are already distributed to food cart vendors, and each vending spot has some rental cost (informal). The informal operational rule of food-cart business is the extraction of regular security cash (chanda) by local gang members (mastaan) who are basically part of political parties (related with government) or local trade organisations. Everyday almost all of the food cart vendors pay 100 BDT to 500 BDT to these gang members whereas they also tend to avoid any kind of complaining to the local authority regarding the scenario. These gang members enable the vendors to offer at "their" common spot, furnish them with informal information about police expulsions and contribute as links in negotiations with more powerful local political leaders, as well as petrol police.

The food cart business offers incredible potential advantages as much for labourers and business visionaries with respect to buyers. Sensible arrangement ought to abstain from obstructing the development of this division, while making a good situation for solid rivalry amongst vendors. The concern authority needs to focus on strategic locations under shades considering different facilities (water, electricity, sanitation, etc.) for food cart vendors with suitable action plan. The present study has also identified the location preference around streets/sidewalks/entrances of the vendors is a major cause of traffic blocks and obstacle of pedestrian activities. 
Finally, most of the respondents are Muslim and aware of basic Islamic practices related with halal and haram ingredients in their daily food preparation. In realty, very few can distinguish between the concept of halal and tayyiba. One of the interviewees shows his inability to detect the concept of halalan tayyiba as:

[...] my ingredients are $100 \%$ halal and I am a muslim. I always prepare my foods using halal ingredients. Eating halal is a complete blessings from Allah SWT.

In focussed food cart business segment, the concept of halalan tayyiba obtained very limited exposure. Usually, in the halal market for individuals to use the terms halal and halalan tayyiba conversely because of a recognition that whatever is halal, is likewise halalan tayyiba. All things considered, the two terms convey two distinct implications. The previous suggests consistence with essential Islamic parameters, while the last goes past those basics to summon upgraded highlights that make something great, pure and healthy. From the regulatory perspective, for instance, the laws and regulations related to this concept seems very limited in comparison to those governing the halal concept. However, the findings basically uncovers that the idea of halalan tayyiba can possibly be actualised in the methodology for the assurance of halal and safe street foods in Bangladesh and it has been interpreted as an application alluded to the reference standard.

\section{Significance of the study}

The study attempts to contribute to the existing body of knowledge by identifying major concerns related with unstructured food cart business activities. This research is may, perhaps, one of the initial attempts to consider the role of halalan tayyiban principle as one of the vital ways to comply with how food cart business development concerns and hygiene practices are a part of the halal idea in the context of Bangladesh. It embraces of values that are not just for Muslim people but for every religion or race. The research has also extended the literature in terms of explorative studies on Islamic micro entrepreneurship and halal food consumption models. On the other hand, the study also provides new theoretical insights about different factors improving the understanding for authority or other stakeholders by integrating halalan tayibban outline. However, the uncovered critical issues related with food security, weather, lack of proper legislation and lack of awareness can possibly support concerned authority to identify the critical factors to implement appropriate tactical activities towards local economic advancements on basis of halalan tayyiba.

The outcomes of the study also provide the interpretation that the concept of halalan tayyiban standards or consciousness can possibly the determinant for a consumer to formulate an affirmative mind setup towards halal foods selling from different food carts. Again, it reflects that the more concerned food cart vendors with the idea of halalan tayyiban, the more affirmative mind setup they hold towards sustainable street food business. Thus, halal street foods are appreciated or approved by all types of consumers because of the adoption within halalan tayyiban outline. At this point, the food cart vendors may possibly able to promote the concept of halalan tayyiban and attitude in their communications process. The strategy can embrace of the integration of tagline such as $100 \%$ halal and healthy, $100 \%$ halal and hygienic or $100 \%$ halal and organic/natural. So, the local policymakers can use this insight of the present study to review or reformulate the outline related to sustainable marketing of the local food cart business segment to attract domestic and international food travellers. 
RAMJ

16,1

Future recommendation of the study

The idea of halalan tayibban adoption for food cart business advancement has opened the way for future research in disciplines of humanities or food sciences. The concerns of limited resources, consciousness and arguable regulations according to conventional food handling practices inside food cart business segment of Chittagong, partially contradicts the Islamic "tasawur", which holds connections with community and nature. The concern of "tasawur" on the halalan tayyiban outline for food-related business is constructed on basis of the traditional social science framework, which has focussed the profitability dimension as the main objective. Hence, future studies need to focus on the missing links concerning the adoption of halalan tayyiban outline aligned with the perspective of "tasawur", which is basically based on Islam. In addition, comparative studies focussing on cognitive areas of food cart vendors and consumers are also necessary to be steered, as such investigations may possibly worthy for producers and marketers of halal business industry. This article deals with previously ignored topics of research, thus this exploration is restricted to one country under investigation. Further work, therefore, needs to be expanded to other countries such as Hong Kong, Singapore, Malaysia, China and Thailand where street food vendors are so popular.

\section{Limitations of the study}

The main impediment to note is that as an exploratory investigation, with just a little sample, the discoveries are restricted in how far they can be summed up over the entire of the food cart business segment in Chittagong. In any case, regardless of this, it is felt that the signs from the different stakeholders do have both pertinence and potential for incorporation in suggestions. However, each of the interviews were semi-structured, it was noticed that a portion of the participants were not as expected with information as others, and it created the impression that not all inquiries were comprehended similarly over every one of the interviewees. This brought about a few irregularities between interviews regarding the inquiries replied. Likewise, explorative research includes generally little quantities of participants and the discoveries of this exploration are perceived to be from a little sample size. The information gathered was confined to Chittagong metropolitan city because of impediments of time, spending plan and accessible samples. The outcomes ought to be translated in light of these constraints. A last restriction is that clients of street foods were not met as a piece of this examination. Having recognised the constraints, the present research requests advance investigation with respect to this point in the coming future.

\section{Conclusion}

The quality, safety and growth of food cart business segment are controlled by various factors, for example, the business association, administrative viewpoints, legal outline, technology, protection, the customer point of view and instructive projects. Above all else need is to assemble proper awareness that street food sellers ought to keep up certain quality of standard. Accordingly, the idea of halalan tayyiba can possibly hold the potential to emerge as a suitable development framework to determine halal and healthy street food products as it reflects both physical and spiritual benefits for human beings. As a result, the legislation and policy would need to be outlined equitably and food cart vendor registration fees charged should be sustainable so that vendors are able to stay within the regulatory consideration. Matter of fact, the authority needs to embrace food cart business as a dynamic economic segment directed towards the concept of halalan tayyiba outlines. With their adaptability to the frenetic life in the global cities, food cart vendors have a huge potential to quickly fill niches, greatly improving urban access to food. As a 
result, related organisations including authority, policy specialists, consumers and vendors are, hence, energised as this should prompt the shift of halalan tayyiba focussed business status and take into account the change of the occupations of sellers and their families.

\section{References}

Adhikari, D.B. (2017), "Informal street food trade: a source of income generation in urban Nepal", Economic Journal of Development Issues, Vol. 23 Nos 1/2, pp. 1-17.

Al Mamun, M., Rahman, S. and Turin, T. (2013), "Microbiological quality of selected street food items vended by school-based street food vendors in Dhaka", International Journal of Food Microbiology, Vol. 166 No. 3, pp. 413-418.

Ali, M., Khan, M. and Saha, M. (2012), "Antibiotic resistant patterns of bacterial isolates from ready-toeat (RTE) street vended fresh vegetables and fruits in Dhaka city", Bangladesh Journal of Scientific Research, Vol. 24 No. 2.

Alimi, B. (2016), "Risk factors in street food practices in developing countries: a review", Food Science and Human Wellness, Vol. 5 No. 3, pp. 141-148.

Alzeer, J., Rieder, U. and Abou Hadeed, K. (2018), "Rational and practical aspects of halal and tayyib in the context of food safety", Trends in Food Science and Technology, Vol. 71, pp. 264-267.

Arif, S. and Sidek, S. (2015), "Application of halalan tayyiban in the standard reference for determining Malaysian halal food”, Asian Social Science, Vol. 11 No. 17.

Batréau, Q. and Bonnet, F. (2016), "Managed informality: regulating street vendors in Bangkok", City and Community, Vol. 15 No. 1, pp. 29-43.

Bendech, A., Malvy, D.J. and Chauliac, M. (1997), "Vitamin A deficiency: epidemiological aspects and control methods", Sante (Montrouge, France), Vol. 7 No. 5, pp. 309-316.

Bhowmik, S. (2012), Street Vendors in the Global Urban Economy, Taylor \& Francis.

Bhuvaneshwari, P. and Venkatachalam, C. (2018), "Street business keeps the poverty aside: a sociological observation from Salem city of Tamil Nadu", International Journal of Research in Social Sciences, Vol. 8 No. 11, pp. 790-800.

Bohari, A.M., Hin, C.W. and Fuad, N. (2017), "The competitiveness of halal food industry in Malaysia: a SWOT-ICT analysis", Geografia-Malaysian Journal of Society and Space, Vol. 9 No. 1.

Bromley, R. (2000), "Street vending and public policy: a global review", International Journal of Sociology and Social Policy, Vol. 20 Nos 1/2, pp. 1-28.

Bruton, G., Ahlstrom, D. and Li, H. (2010), "Institutional theory and entrepreneurship: where are we now and where do we need to move in the future?", Entrepreneurship Theory and Practice, Vol. 34 No. 3, pp. 421-440.

Bujisic, M., Bogicevic, V. and Parsa, H. (2016), "The effect of weather factors on restaurant sales", Journal of Foodservice Business Research, Vol. 20 No. 3, pp. 350-370.

Di Matteo, D. and Cavuta, G. (2016), "Enogastronomic tourism: can it mitigate the intangibility of the destination? Street food as a new business model for the management of tourist regions", Procedia Economics and Finance, Vol. 39, pp. 347-356.

Frank, A. (2015), "Assessment of food safety knowledge and attitude of street food consumers in the Kumasi metropolis", SSRN Electronic Journal, doi: 10.2139/ssrn.2727705.

Ghatak, I. and Chatterjee, S. (2018), "Urban street vending practices: an investigation of ethnic food safety knowledge, attitudes, and risks among untrained Chinese vendors in Chinatown", Kolkata. Journal of Ethnic Foods, Vol. 5 No. 4, pp. 272-285.

Hackenbroch, K. (2013), "Negotiating public space for livelihoods: about risks, uncertainty and power in the urban poor's everyday life", Erdkunde, Vol. 67 No. 1, pp. 37-47. 
RAMJ

16,1

Hassan, H. (2018), "Determinants and effects of the informal economy: Bangladesh perspective", Janata Bank Journal of Money, Finance and Development, Vol. 5, pp. 197-208.

International Association for Food Protection (2015), "Journal of food protection", available at: https:// www.foodprotection.org/publications/journal-of-food-protection/ (accessed 27 September 2018).

Islam, M. (2015), "Print media and governance in Bangladesh: a critical reading", Asian Politics and Policy, Vol. 7 No. 2, pp. 341-344.

Islam, N. (2016), "Factors influencing the development of women entrepreneurship in Bangladesh", SSRN Electronic Journal, doi: 10.2139/ssrn.2851786.

Jacobs, J. (1969), The Economy of Cities, Random House, New York, NY.

Khairuzzaman, M., Chowdhury, F., Zaman, S., Al Mamun, A. and Bari, M. (2014), "Food safety challenges towards safe, healthy, and nutritious street foods in Bangladesh", International Journal of Food Science, Vol. 2014, pp. 1-9.

Martínez, L., Short, J.R. and Estrada, D. (2017), "The urban informal economy: street vendors in Cali, Colombia”, Cities, Vol. 66, pp. 34-43.

MIFC (2015), Halal Ecosystem: Prospects for Global Growth, Malaysia International Islamic Financial Centre, Malaysia.

Muhamad, N., Leong, V. and Mizerski, D. (2016), "Consumer knowledge and religious rulings on products”, Journal of Islamic Marketing, Vol. 7 No. 1, pp. 74-94.

Muzaffar, A., Huq, I. and Mallik, B. (2009), "Entrepreneurs of the streets: an analytical work on the street food vendors of Dhaka city", International Journal of Business and Management, Vol. 4 No. 2.

Nani, G.V. (2016), "A synthesis of changing patterns in the demographic profiles of urban street vendors in Botswana, South Africa and Zimbabwe", Problems and Perspectives in Management, Vol. 14 No. 3 (contin. 2), pp. 549-555.

Nayansi, N., Atul Anand, M., Shukla, R.N, S. and Ankita, A. (2012), "Analysis of practices of street food vendors and sensory assessment of street foods (fast foods and juices) in Allahabad city, (U.P.) India”, International Journal of Scientific Research, Vol. 3 No. 8, pp. 132-135.

Nisha, N. and Iqbal, M. (2017), "Halal ecosystem: prospect for growth in Bangladesh", International Journal of Business and Society, Vol. 18, pp. 205-222.

Peng, M. (2001), "How entrepreneurs create wealth in transition economies", Academy of Management Perspectives, Vol. 15 No. 1, pp. 95-108.

Pinstrup-Andersen, P. (2000), "Food policy research for developing countries: emerging issues and unfinished business", Food Policy, Vol. 25 No. 2, pp. 125-141.

Pritchard, B. and Chan, Y. (2016), "The new consumer politics of food in East Asia: food safety, food scares and 'eating right”, Asia Pacific Viewpoint, Vol. 57 No. 3, pp. 297-300.

Proietti, I., Frazzoli, C. and Mantovani, A. (2014), "Identification and management of toxicological hazards of street foods in developing countries", Food and Chemical Toxicology, Vol. 63, pp. 143-152.

Rahim, A. and Choudhury, R. (2015), "Perceived role of dietary fiber in healthy diet and its intake pattern among educated urban population", Bangladesh Journal of Nutrition, Vol. 18, p. 61.

Rahman, M. (2016), "Sustainable food security of Bangladesh”, International Journal of Nutritional Science and Food Technology, Vol. 2 No. 2, pp. 79-88.

Rahman, M.M., Arif, M.T., Bakar, K. and Bt Talib, Z. (2016), "Food safety knowledge, attitude and hygiene practices among the street food vendors in Northern Kuching city, Sarawak", Borneo Science.

Redzwan Habib, K. (2016), "Understanding challenges faced by street food vendors to maintain street food hygiene in Dhaka city", Journal of Food and Nutrition Sciences, Vol. 4 No. 4, p. 78.

Rezai, G., Mohamed, Z. and Shamsudin, M. (2015), "Can halal be sustainable? Study on Malaysian consumers' perspective”, Journal of Food Products Marketing, Vol. 21 No. 6, pp. 654-666. 
Sen, S., Savitskie, K., Ranganathan, S. and John, R. (2018), "Food truck operators provide business insights", Global Fashion Management Conference, Vol. 2018, pp. 530-530.

Shafiee, N.F., Karim, M., Razali, A. and Abidin, U.Z. (2017), "Halalan toiyyiban food handling practices: a review on street food vendors in Malaysia", Journal of Islamic, Social, Economics and Development (JISED), Vol. 2, pp. 385-394.

Shamtsyan, M. (2013), "Food legislation and its harmonization in Russia", Journal of the Science of Food and Agriculture, Vol. 94 No. 10, pp. 1966-1969.

Shane, S. and Foo, M. (1999), "New firm survival: institutional explanations for new franchisor mortality", Management Science, Vol. 45 No. 2, pp. 142-159.

Sharma, P. (2017), "Assessment of hygiene status and environmental conditions among street food vendors in South-Delhi, India", Epidemiology International, Vol. 2 No. 3, pp. 4-9.

Sigwele, T.C., Letsholo, B., Ndabambi, N., Coetzee, T., Wale, K., Khare, K.B. and Loeto, D. (2017), "Determination of antibiotic resistance and enterotoxigenic potential of Staphylococcus aureus strains isolated from foods sold by street vendors in Gaborone, Botswana".

Sizonenko, V. (2013), "Entrepreneurship development in a context of the institutional theory", Bulletin of Taras Shevchenko National University of Kyiv Economics, No. 148, pp. 24-27.

Truong, V.D. (2018), "Tourism, poverty alleviation, and the informal economy: the street vendors of Hanoi”, Tourism Recreation Research, Vol. 43 No. 1, pp. 52-67.

Ul Ain, H. (2017), "The haram halal of food and art in Pakistan”, Performance Research, Vol. 22 No. 7, pp. 148-152.

Warr, P. (2014), “Alleviating food insecurity in Asia”, World Food Policy, Vol. 1 No. 2.

Webb, M. and Morancie, A. (2015), "Food safety knowledge of foodservice workers at a university campus by education level, experience, and food safety training", Food Control, Vol. 50, pp. 259-264.

Weik, E. (2011), "Institutional entrepreneurship and agency", Journal for the Theory of Social Behaviour, Vol. 41 No. 4, pp. 466-481.

Zailani, S., Iranmanesh, M., Jafarzadeh, S. and Foroughi, B. (2019), "The influence of halal orientation strategy on financial performance of halal food firms", Journal of Islamic Marketing, Vol. 11 No. 1.

Zainuddin, A. and Shariff, S. (2016), "Preferences for halalan toyyiban retail supply chain certification: a case of hypermarket", Procedia Economics and Finance, Vol. 37, pp. 405-411.

\section{Further reading}

Batchelder, W. and Alexander, G. (2012), "Insight problem solving: a critical examination of the possibility of formal theory", The Journal of Problem Solving, Vol. 5 No. 1.

Castellano, U. (2011), "Problem-solving courts: theory and practice", Sociology Compass, Vol. 5 No. 11, pp. $957-967$.

Dostál, J. (2015), "Theory of problem solving", Procedia - Social and Behavioral Sciences, Vol. 174, pp. 2798-2805.

Timmer, C. (2017), "Food security, structural transformation, markets and government policy", Asia and the Pacific Policy Studies, Vol. 4 No. 1, pp. 4-19.

\section{Corresponding author}

Ariful Islam can be contacted at: farhan_ctg2012@yahoo.com

For instructions on how to order reprints of this article, please visit our website:

www.emeraldgrouppublishing.com/licensing/reprints.htm

Or contact us for further details: permissions@emeraldinsight.com 